NOTE

\title{
First case of ranavirus-associated morbidity and mortality in natural populations of the South American frog Atelognathus patagonicus
}

\author{
Stanley F. Fox ${ }^{1, *}$, Amy L. Greer ${ }^{2}$, Ricardo Torres-Cervantes ${ }^{1}$, James P. Collins ${ }^{2}$ \\ ${ }^{1}$ Department of Zoology, 430 LSW, Oklahoma State University, Stillwater, Oklahoma 74078, USA \\ ${ }^{2}$ School of Life Sciences, Arizona State University, PO Box 874501, Tempe, Arizona 85287, USA
}

\begin{abstract}
Atelognathus patagonicus is an endangered leptodactylid frog endemic to a small region in and around Laguna Blanca National Park in northern Patagonia, Argentina. All of the lakes and small ponds of the region (except Laguna Blanca itself) contain A. patagonicus and in all but one of these lakes the species shows clinical signs of a previously undiagnosed disease, the characteristics of which suggested a ranavirus. We collected symptomatic and asymptomatic A. patagonicus frogs and tadpoles from 4 small lakes and analyzed tissues for ranavirus and the chytrid fungus Batrachochytrium dendrobatidis using PCR amplification of pathogen DNA. Of the 32 specimens tested, 25 were positive for ranavirus major capsid protein (MCP). Sequence alignments of the ranavirus MCP from these specimens showed $100 \%$ similarity with published FV3 and FV3-like viruses from anurans, 98 to $99 \%$ similarity with Bohle iridovirus, and 95\% similarity with Ambystoma tigrinum virus (ATV) and Regina ranavirus (RRV). A search of the NCBI Blast nucleotide database using the 500 base pair MCP sequence obtained from these samples did not suggest any homology to any other pathogen. In addition, 1 sample ( 3 pooled individuals) from 1 lake tested positive for $B$. dendrobatidis. The clinical signs observed primarily in late-stage tadpoles and recent metamorphs, which have reoccurred each year since at least 2001, are consistent with ranaviral disease, but until histopathology of diseased individuals is carried out, chytridiomycosis or other diseases cannot be ruled out.
\end{abstract}

KEY WORDS: Amphibian · Disease · Invasive fish · Argentina · Ranavirus · Chytrid . Batrachochytrium dendrobatidis $\cdot$ Patagonia

\section{INTRODUCTION}

Atelognathus patagonicus is a leptodactylid frog endemic to a system of endorheic lakes and ponds in and around Laguna Blanca National Park in the province of Neuquén in NW Patagonia in Argentina (Cei 1980). The species was highly abundant when first collected in the principal lake of the region, Laguna Blanca $\left(39^{\circ} \mathrm{S}, 70^{\circ} \mathrm{W} ; 1276 \mathrm{~m}\right)$, in 1948 (Gallardo 1962), and in subsequent years (Péfaur \& Duellman 1980). It was the most abundant amphibian in the lake until the late 1970s (Administración de Parques Nacionales 1993); however, it declined sharply in num- bers in the mid-1980s in Laguna Blanca (Administración de Parques Nacionales 1993). The species is now apparently extinct in Laguna Blanca, and presently found only in nearby smaller lakes and ponds (Fox et al. 2005).

Atelognathus patagonicus is listed as 'endangered' by the International Union for Conservation of Nature and Natural Resources (IUCN) ${ }^{1}$, and as 'vulnerable' by the Secretaría de Agricultura y Ganadería in 1983 and by Grigera \& Úbeda in 1997, and is currently under

${ }^{1}$ IUCN, Conservation International, and NatureServe (2004) Global amphibian assessment (www.globalamphibians.org) 
consideration for listing as 'in danger of extinction' by the Dirección Nacional de Fauna y Flora Silvestres upon the suggestion of the Argentine Herpetological Association (Lavilla et al. 2000). It is listed as a 'special value species' by the Administración de Parques Nacionales (1994).

The disappearance of Atelognathus patagonicus from Laguna Blanca appears to be related to the introduction of an invasive, carnivorous perch Percichthys colhuapiensis, which occurred without authorization in 1965 (Administración de Parques Nacionales 1993). Before this, no species of fish had inhabited Laguna Blanca (Daciuk 1968), or any other water body of the system. The perch established as a large, reproductive population and has altered the lake environment to a great extent (Ortubay et al. 2006). The disappearance of A. patagonicus from Laguna Blanca might be attributable simply to this invasive fish species, either directly via predation or competition (Fox et al. 2005), or indirectly via limnological changes (Ortubay et al. 2006), but the situation appears more complex. According to the Administración de Parques Nacionales (1993), the frog remained very abundant until 1983, grew scarce in 1984, and from 1986 on has not been observed - i.e. a rather abrupt extirpation some $21 \mathrm{yr}$ after $P$. colhuapiensis was introduced.

In an extensive survey of the status and distribution of Atelognathus patagonicus during 2001 and 2002, Fox et al. (2005) found dense populations in all of 14 smaller water bodies sampled near Laguna Blanca (but none in that lake). They also discovered high levels of clinical signs of disease in all but one of the populations sampled (very few individuals were sampled in this 1 exception), and appreciable levels of dead frogs (up to $33 \%$ in 1 lake) in 10 of 11 lakes sampled quantitatively. The frequency of sick frogs for all lakes pooled in 2001 peaked (47\%) in February (austral midsummer), then decreased to a low $1.4 \%$ in April (early austral fall). Affected populations apparently were able to sustain the observed levels of morbidity and mortality; population densities in the second (Fox et al. 2005) and subsequent years (M. E. Cuello pers. comm.) remained high, as did the frequency of sick individuals. It may be that this disease recurs annually and that the frog populations (without any other additional environmental challenge) can 'afford' the morbidity and mortality (Bradley et al. 2002, Carey et al. 2003, Brunner et al. 2004), especially among tadpoles and recent metamorphs.

Disease is responsible for a number of population declines and extinctions of amphibian populations around the world. Especially 2 diseases, the chytrid fungus Batrachochytrium dendrobatidis and the iridovirus genus Ranavirus, have been responsible for worldwide die-offs and declines (Carey et al. 2003,
Collins et al. 2003, Daszak et al. 2003). The fungus $B$. dendrobatidis is responsible for amphibian die-offs and population declines worldwide - in Australia (Berger et al. 1998), Central and South America (Lips 1999, Ron \& Merino 2000, Young et al. 2001), Europe (Bosch et al. 2001) and North America (Daszak et al. 1999, Green et al. 2002, Muths et al. 2003). Ranaviruses have caused massive amphibian die-offs in wild populations of the United Kingdom, United States, and Canada (Daszak et al. 1999, Green et al. 2002, Carey et al. 2003). From the presentation of the clinical symptoms in wild populations of Atelognathus patagonicus, Fox et al. (2005) suspected infection by some ranavirus species or isolate (genus Ranavirus).

Our objective was to sample Atelognathus patagonicus from several populations to diagnose the presumptive pathogen(s), looking specifically for Ranavirus, and the chytrid fungus Batrachochytrium dendrobatidis.

\section{MATERIALS AND METHODS}

Field. We collected Atelognathus patagonicus from 4 small lakes (Lagunas Antiñir, del Hoyo, del Molle and Verde) within Laguna Blanca National Park $\left(39^{\circ} \mathrm{S}\right.$, $\left.70^{\circ} \mathrm{W} ; 1276 \mathrm{~m}\right)$, Neuquén, Argentina, during February (austral mid-summer) 2004. We took every precaution to avoid cross-contaminating possible pathogens between ponds by strictly following the guidelines of the 'DAPTF Fieldwork Code of Practice' (DAPTF: Declinig Amphibians Populations Task Force) and those outlined in Lips et al. (2001). All boots, gloves, nets and other equipment were scrubbed with a bleach solution after being used in a given lake before sampling another lake, and no frogs or tadpoles were moved from one lake to another. The frogs were categorized into 4 levels of clinical signs of disease: none, light, moderate and heavy. We collected 8 subjects (6 with clinical signs and 2 without, both tadpoles of Gosner [1960] Stages 34 to 41 and recent metamorphs) from each of the 4 lakes for ranavirus analysis. The frogs were collected live, anesthetized in buffered $1 \%$ tricaine methanesulfonate (MS-222), and flash frozen whole in liquid nitrogen. They were then stored in liquid nitrogen until air transport on dry ice to Oklahoma State University, where they were stored for a few weeks in a supercold freezer at $-60^{\circ} \mathrm{C}$, then mailed overnight on dry ice to Arizona State University. We collected samples for Batrachochytrium dendrobatidis analysis from 9 subjects from each of the 4 lakes $(\mathrm{N}=36)$. All subjects showed clinical signs of disease, and we sampled both late-stage tadpoles (Gosner Stages 34 to 41 ) and recent metamorphs. The skin (dorsum, venter, thighs) and (for tadpoles), mouthparts 
of these individuals were scraped with a clean, wooden, edged toothpick, which was then transferred to a small vial with $70 \%$ ethanol, and stored upright, unrefrigerated. We pooled toothpick samples from 3 individuals from each lake; thus we had 3 vials from each lake each with samples from 3 individuals. In handling specimens for both analyses, we were careful to avoid cross-contamination by using fresh, disposable rubber gloves for each subject.

Laboratory. Whole frozen specimens were sent to the laboratory of J. P. Collins at Arizona State University for PCR analysis for the presence of ranavirus DNA. We collected 2 small tissue samples (liver, spleen, gastro-intestinal tract, and body wall, combined) from each individual and placed these in separate tubes containing $300 \mu \mathrm{l}$ of lysis buffer. Total cellular DNA was extracted from tissues using a modified Puregene $^{\odot}$ extraction protocol for animal tissues. Amplification was conducted using primers specific for a 500 base pair fragment of the ranavirus major capsid protein (MCP) (Mao et al. 1997) in $15 \mu$ reactions. Thermocycling conditions were similar for all samples $\left(94^{\circ} \mathrm{C}\right.$ for $5 \mathrm{~min}, 94^{\circ} \mathrm{C}$ for $30 \mathrm{~s}, 55^{\circ} \mathrm{C}$ for $30 \mathrm{~s}$ and $72^{\circ} \mathrm{C}$ for $30 \mathrm{~s}$, cycled 35 times followed by an extension of $72^{\circ} \mathrm{C}$ for $2 \mathrm{~min}$ ). Both positive and negative controls were tested alongside all unknown samples to assess both carryover and reagent contamination. Positive controls were obtained from Ambystoma tigrinum experimentally infected with ATV (A. tigrinum ranavirus). All amplified products were stained with Sybergreen and visualized by electrophoresis on $1 \%$ agarose gels. PCR products were cleaned using Montage columns and then sequenced on an ABI 3730 capillary sequencer. The resulting 500 base pair sequences of the amplified product were aligned using Sequencer 4.1.4 software and compared to published sequences using the NCBI Blast Search nucleotide database.

Toothpick scrapings were sent to John Wood, Pisces Molecular, Boulder, Colorado, for PCR analysis for diagnostic DNA of Batrachochytrium dendrobatidis. For each sample, the sample liquid was mixed by pipetting up and down; then the entire volume, including any visible skin/tissue pieces, was transferred to a microfuge tube. After spinning at maximum speed in a microcentrifuge $(\sim 16000 \times g)$ for $3 \mathrm{~min}$, the supernatant was drawn off and discarded, tissue lysis buffer was added, and any pellet was resuspended by vortexing. We added $10 \mu \mathrm{g}$ of carrier DNA per sample to the lysis buffer. Total DNA was extracted from all samples using a spin-column DNA purification procedure. The sample DNA preparations were assayed for the presence of the $B$. dendrobatidis ribosomal RNA intervening transcribed sequence (ITS) region by 45 cycle single-round PCR amplification using an assay developed by Annis et al. (2004) and modified for greater speci- ficity and sensitivity at Pisces Molecular. Each PCR run included 3 controls. (1) Positive DNA: DNA prepared from a laboratory culture of $B$. dendrobatidis, Strain JEL 270, kindly provided by Dr. Joyce Longcore, University of Maine; this sample was previously demonstrated to be positive by PCR, and the signal from this sample was the standard for a strong positive (++) signal. (2) Negative DNA: DNA prepared from a laboratory culture of a non- $B$. dendrobatidis chytrid fungus, Strain JEL 151, kindly provided by J. Longcore; this sample was previously demonstrated to be negative (-) by PCR. (3) No DNA: $\mathrm{H}_{2} \mathrm{O}$ in place of template DNA; this reaction remained uncapped during addition of sample DNA to the test reactions, and served as a control to detect contaminating DNA in the PCR reagents or carryover of positive DNA during reaction set-up.

\section{RESULTS AND DISCUSSION}

Clinical signs of disease occurred in metamorphosing tadpoles and recent metamorphs. No adult individuals were affected. Sick tadpoles had hemorrhages in the tail, abdomen, back legs and throat; swollen, greatly distended abdomen from edema in the body cavity; frequent excretion of bloody mucus from the vent; impaired swimming ability and proper buoyancy; labored respiration; and frequent death upon capture. Affected postmetamorphs had intense redness of the venter (thighs and abdomen); white blotches on the dorsum; edema on the throat; impaired locomotion; and frequent death upon capture. Hemorrhages in the spleen and liver suggested a systemic infection. Due to severe restrictions on the number of specimens we were allowed to collect, histopathological examination was not performed.

Of the 32 specimens tested, 25 were positive for ranavirus MCP (with positives in all 4 lakes sampled). DNA re-extracted from the 7 negative specimens and amplified by PCR again scored negative. Sequence alignments of the ranavirus MCP from these samples showed $100 \%$ similarity with published FV3 and FV3like viruses from anurans, 98 to $99 \%$ similarity to Bohle iridovirus, and $95 \%$ similarity to Ambystoma tigrinum virus (ATV) and Regina ranavirus (RRV). A search of the NCBI Blast nucleotide database using the 500 base pair MCP sequence obtained from these samples does not suggest any homology to other pathogens. Of the 12 tubes (each containing skin scrapings from 3 individuals) tested, 1 was strongly positive for the chytrid fungus Batrachochytrium dendrobatidis $(++$, where +++ is the strongest signal). Thus, 1 to 3 individuals from 1 lake (Laguna del Molle) were infected with the chytrid fungus. Without a much larger survey for both $B$. dendrobatidis and the ranavirus and without 
histopathological examamination of tissues of diseased individuals, we cannot conclusively attribute the morbidity and mortality we observed in Atelognathus patagonicus to a ranavirus, $B$. dendrobatidis, or any other pathogen. We did find a much higher incidence of ranavirus than $B$. dendrobatidis, however, and in field surveys of various lakes in the area conducted during this study we found a significant incidence of disease in tadpoles and recent metamorphs $(18.5 \%, \mathrm{~N}$ = 1164), but none in adults $(\mathrm{N}=66)$. Ranaviral disease is more frequent in tadpoles and recent metamorphs than is chytridiomycosis (Green et al. 2002, Collins et al. 2003). Nevertheless, complete histopathology of diseased individuals collected at a much larger scale is needed.

As far as we know, this is the first documented case of significant morbidity and mortality associated with a ranavirus in natural populations of a South American amphibian (Carey et al. 2003, Collins et al. 2003), even though we cannot unequivocally conclude that it was the ranavirus causing the disease and dieoffs. Various isolates of an iridovirus (Guatopo virus) have previously been documented from wild populations of Bufo marinus and a Leptodactylus frog species in Venezuela (Zupanovic et al. 1998), but did not associate with significant population die-offs. Isolates very homologous to species of the genus Ranavirus have also been identified via the PCR technique from tissues of cultured bullfrogs Rana catesbeiana in Brazil and Uruguay (Galli et al. 2006). This is the second case of Batrachochytrium dendrobatidis to be reported in Argentina (first case recently reported by Herrera et al. [2005] in Leptodactylus ocellatus from the province of Buenos Aires). Virus cultures were prepared from homogenized tissues of infected individuals and passed in Epithelioma Papulosum Cyprini (EPC) cells. Inoculated EPC cells grown at room temperature $\left(\sim 20^{\circ} \mathrm{C}\right)$ demonstrated a cytopathic effect (CPE). Work is currently underway to further characterize the identified ranavirus. Preliminary cultures established from infected frogs demonstrated a clear cytopathic effect, as would be expected with a ranavirus. Hyatt et al. (2000), using data drawn from ranavirus genome sequences of PCR products, constructed a phylogeny in which all B. marinus isolates of the Venezuelan Guatopo virus (GV) fell into the same distal clade (most derived of the entire set of 19 iridoviruses isolates from around the world) whose sister taxon was the GV isolated from an unknown species of Leptodactylus, also from Venezuela.

While we recognize that amphibians are susceptible to diseases other than Batrachochytrium dendrobatidis and ranaviruses, in this preliminary study we focused on these 2 diseases because of their implication in global amphibian declines (Carey et al. 2003, Collins et al. 2003, Daszak et al. 2003). Even though we assayed for the presence of only these 2 pathogens, we found both. Our results are the first evidence for ranaviruses and the second observation for $B$. dendrobatidis in the southern cone of South America. As stated previously, however, it is necessary to sample more diseased individuals and conduct good histopathology on them to find out if $B$. dendrobatidis or a ranavirus is truly responsible for the morbidity and mortality, or if even some other pathogen is involved. As far as we know, no other cases of any amphibian disease have been reported from this area of the world, and no disease accounts in any species of Atelognathus have previously been reported. Of the 8 species of Atelognathus (all indigenous to Patagonia) 6 are categorized with some degree of conservation concern (Úbeda et al. 1999, IUCN), due primarily to restricted geographic distributions and anthropogenic threats to habitat integrity. Data on the other 2 Atelognathus species are too deficient to allow evaluation of their conservation status.

The ecological characteristics of Atelognathus patagonicus favor infectious disease, including ranaviral epizootics (Daszak et al. 1999). The ecology of this species resembles that of Ambystoma tigrinum of the western US (Jancovich et al. 1997, Carey et al. 2003) and Rana temporaria of Great Britain (Cunningham et al. 1995), both of which experience recurrent ranavirus epizootics (Daszak et al. 2003). Tadpoles of Atelognathus patagonicus group together under flat rocks in the day and reach high densities (Fox et al. 2005). Populations inhabit small ponds and lakes with substantial anthropogenic habitat degradation. These small lakes are visited by livestock and waterfowl, which might carry the pathogenic virus from lake to lake (Daszak et al. 1999). It is not known if adults leave the lakes during the non-breeding season or whether they perhaps seek refuge in the deeper parts of the lakes. Few adults have been observed in late-winter to early spring shoreline surveys (Cuello 2002, S. F. Fox pers. obs.) where tadpoles, recent metamorphs and adults are seen in abundance later in the season. Thus, it is not known if Atelognathus patagonicus has an intraspecific reservoir similar to Ambystoma tigrinum (Brunner et al. 2004). However, we observed that clinical signs of late-stage tadpoles held in captivity for up to $1 \mathrm{wk}$ sometimes disappeared, implying that 'recovery' of infected individuals might occur, even though they might still carry the virus.

This is one of the rare cases in which the same amphibian population carries both ranavirus and Batrachochytrium dendrobatidis pathogens. Green et al. (2002), Carey et al. (2003) and Daszak et al. (2003), reported no instance of sympatry of both pathogens. Both B. dendrobatidis and ranavirus (Ambystoma 
tigrinum virus) have been reported in A. tigrinum of southern Arizona (Jancovich et al. 1997, Davidson et al. 2003), and B. dendrobatidis and an unknown species of ranavirus have been found in Central America (K. Lips pers. comm.).

Fox et al. (2005) proposed that Atelognathus patagonicus disappeared from Laguna Blanca due to the combined effect of a negative interaction with the introduced perch and some other stressor, especially since the 2 species coexisted in Laguna Blanca for more than 20 yr. Perhaps this other stressor was the disease that is still present in extant populations and spread there by migration of infected frogs moving from one lake to another or, more likely, in water carried by waterfowl and livestock, which frequently move from lake to lake (S. F. Fox pers. obs.). It is also possible that the disease spread among lakes from infected frog tissue carried on the bills or feathers of the waterfowl. Because fish are not present and have never been present in the other lakes, the frog populations have persisted, despite the presence of sick individuals and significant deaths.

Although the ranavirus infecting tiger salamanders in the western US does not appear to spread to fish (Jancovich et al. 2001), some iridoviruses may jump hosts from fish to amphibians (Mao et al. 1999, Jancovich et al. 2005). The possibility that the suspected disease arrived with the introduction of the invasive Percicthys colhuapiensis deserves further study. In any case, it is imperative that $P$. colhuapiensis is kept from invading extant populations of endangered Atelognathus patagonicus.

Acknowledgements. We especially thank S. Perea-Fox for her field assistance and help in a myriad of ways. We also thank Q. Vidoz, C. Erviti, O. Martínez, I. Immerman, S. Domber, and C. Quilaquéo, for their logistical aid, and J. Wood for laboratory assays. We appreciate the assistance of C. Chehébar and E. Ramilo of the Delegación Técnica of the Administración de Parques Nacionales in Bariloche for making this study possible. Financial and other support came from RANA (NSF Award DEB-0130273 to B. Young), the College of Arts and Sciences and the Department of Zoology of Oklahoma State University, an NSERC postgraduate fellowship to A.L.G., and NSF grant No. IBN 9977063 (Integrated Research Challenges in Environmental Biology) to J.P.C. Research was conducted under Permit 081 of the Administración de Parques Nacionales, Permit 05/00 of the Province of Neuquén of Argentina, and Permit AS-04-7 of the Oklahoma State University Animal Care and Use Committee.

\section{LITERATURE CITED}

Administración de Parques Nacionales (1993) Plan general de manejo, Parque Nacional Laguna Blanca. Administración de Parques Nacionales, Delegación Técnica Regional Patagonia, Bariloche, Argentina

Administración de Parques Nacionales (1994) Resolución 180/94: lista de vertebrados de valor especial. Parques
Nacionales, Reservas Nacionales y Monumentos Naturales Patagónicos, Buenos Aires, Argentina

Annis SL, Dastoor FP, Ziel H, Daszak P, Longcore JE (2004) A DNA-based assay identifies Batrachochytrium dendrobatidis in amphibians. J Wildl Dis 40:420-428

Berger L, Speare R, Dasak P, Green DE and 10 others (1998) Chytridiomycosis causes amphibian mortality associated with population declines in the rain forests of Australia and Central America. Proc Natl Acad Sci USA 95: 9031-9036

Bosch J, Martínez-Solano I, García-París M (2001) Evidence of a chytrid fungus infection involved in the decline of the common midwife toad (Alytes obstetricans) in protected areas of central Spain. Biol Conserv 97:331-337

Bradley GA, Rosen PC, Sredl MJ, Jones TR, Longcore JE (2002) Chytridiomycosis in native Arizona frogs. J Wildl Dis 38:206-212

Brunner JL, Schock DM, Davidson EW, Collins JP (2004) Intraspecific reservoirs: complex life history and the persistence of a lethal ranavirus. Ecology 85:560-566

Carey C, Bradford DF, Brunner JL, Collins JP and 5 others (2003) Biotic factors in amphibian population declines. In: Linder G, Krest SK, Sparling DW (eds) Amphibian decline: an integrated analysis of multiple stressor effects. Society of Environmental Toxicology and Chemistry (SETAC), Pensacola, FL, p 153-208

Cei JM (1980) Amphibians of Argentina. Monit Zool Ital Monogr 2:1-609

Collins JP, Brunner J, Miera V, Parris M, Schock D, Storfer A (2003) Ecology and evolution of infectious disease. In: Semlitsch RD (ed) Amphibian conservation. Smithsonian Institution Press, Washington, DC, p 137-151

Cuello ME (2002) Atelognathus patagonicus (Anura, Leptodactylidae): distribución, hábitat, fenología y estado de conservación en el Parque Nacional Laguna Blanca y alrededores. Licenciatura thesis, Universidad Nacional de Comahue, Centro Regional Universitario, San Carlos de Bariloche, Argentina

Cunningham AA, Langton TES, Bennet PM, Lewin JF, Drury SEN, Gough RE, MacGregor SK (1995) Investigations into unusual mortalities of the common frog (Rana temporaria) in Britain. In: Zwart P, Matz G (eds) Proc 5th Int Colloq on the Pathology of Reptiles and Amphibians. Alphen Aan Den Rijn, Mar 31-Apr 2, 1995. NRG Repro Facility, Des Hertogenbosch, p 19-27

Daciuk J (1968) La fauna del Parque Nacional Laguna Blanca (estudio zoo-ecológico preliminar). An Parques Nac 11: 225-302

Daszak P, Berger L, Cunningham AA, Hyatt AD, Green DE, Speare R (1999) Emerging infectious diseases and amphibian population declines. Emerg Infect Dis 5:735-748

Daszak P, Cunningham AA, Hyatt AD (2003) Infectious disease and amphibian population declines. Divers Distrib 9:141-150

Davidson EW, Parris M, Collins JP, Loncore JE, Pessier AP, Brunner J (2003) Pathogenicity and transmission of chytridiomycosis in tiger salamanders. Copeia 2003:601-607

Fox SF, Yoshioka JH, Cuello ME, Úbeda C (2005) Status, distribution, and ecology of a threatened semi-aquatic frog (Atelognathus patagonicus) of northwestern Patagonia, Argentina. Copeia 2005:920-928

Gallardo JM (1962) Los géneros Telmatobius y Batrachophrynus (Amphibia, Leptodactylidae) en la Argentina. Neotropica 8:45-58

Galli L, Pereira A, Márquez A, Mazzoni R (2006) Ranavirus detection by PCR in cultured tadpoles (Rana catesbeiana Shaw, 1802) from South America. Aquaculture 257:78-82 
Gosner KL (1960) A simplified table for staging anuran embryos and larvae with notes on identification. Herpetologica 16:183-190

Green DE, Converse KA, Schrader AK (2002) Epizootiology of sixty-four amphibian morbidity and mortality events in the USA, 1966-2001. Ann NY Acad Sci 969: 323-339

Grigera D, Úbeda C (1997) Recategorización del estado de conservación de la fauna de la Patagonia Argentina, Antártida e islas del Atlántico Sur: un análisis de sus resultados. Gayana Zool 61:113-124

Herrera RA, Steciow MM, Natale GS (2005) Chytrid fungus parasitizing the wild amphibian Leptodactylus ocellatus (Anura: Leptodactylidae) in Argentina. Dis Aquat Org 64:247-252

Hyatt AD, Gould AR, Zupanovic Z, Cunningham AA, Hengstberger S, Whittington RJ, Kattenbelt J, Coupar EH (2000) Comparative studies of piscine and amphibian iridoviruses. Arch Virol 145:301-331

Jancovich JK, Davidson EW, Morado JF, Jacobs BL, Collins JP (1997) Isolation of a lethal virus from the endangered tiger salamander Amybstoma tigrinum stebbinsi. Dis Aquat Org 31:161-167

Jancovich JK, Davidson EW, Seiler A, Jacobs BL, Collins JP (2001) Transmission of the Ambystoma tigrinum virus to alternative hosts. Dis Aquat Org 46:159-163

Jancovich JK, Davidson EW, Parameswaran N, Mao J, Chinchar VG, Collins JP, Jacobs BL, Storfer A (2005) Evidence for emergence of an amphibian iridoviral disease because of human-enhanced spread. Mol Ecol 14:213-224

Lavilla EO, Richard E, Scrocchi GJ (2000) Categorización de los anfibios y reptiles de la republica Argentina. Asociación Herpetológica Argentina, San Miguel de Tucumán, Argentina

Editorial responsibility: Otto Kinne,

Oldendorf/Luhe, Germany
Lips KR (1999) Mass mortality and population declines of anurans at an upland site in western Panama. Conserv Biol 13: $117-125$

Lips KR, Reaser JK, Young BE, Ibáñez R (2001) Amphibian monitoring in Latin America: a protocol manual. Soc Study Amphib Reptiles Herpetol Circ 30:1-116

Mao JH, Hedrick RP, Chinchar VG (1997) Molecular characterization, sequence analysis, and taxonomic position of newly isolated fish iridoviruses. Virology 229:212-220

Mao JH, Green DE, Fellers G, Chinchar VG (1999) Molecular characterization of iridoviruses isolated from sympatric amphibians and fish. Virus Res 63:45-52

Muths E, Corn PS, Pessier AP, Green DE (2003) Evidence for disease-related amphibian decline in Colorado. Biol Conserv 110:357-365

Ortubay S, Cussac V, Battini M, Barriga J and 6 others (2006) Is the decline of birds and amphibians in a steppe lake of northern Patagonia a consequence of limnological changes following fish introduction? Aquat Conserv Mar Freshw Ecosyst 16:93-105

Péfaur J, Duellman W (1980) Community structure in high Andean herpetofaunas. Trans Kans Acad Sci 83:45-65

Ron SR, Merino A (2000) Amphibian declines in Ecuador: overview and first report of chytridiomycosis from South America. Froglog 42:2-3

Úbeda C, Zagarese H, Díaz M, Pedroso F (1999) First steps towards the conservation of the microendemic Patagonian frog Atelognathus nitoi. Oryx 33:59-66

Young BE, Lips KR, Reaser JK, Ibáñez R and 10 others (2001) Population declines and priorities for amphibian conservation in Latin America. Conserv Biol 15:1213-1223

Zupanovic Z, Musso C, Lopez G, Louriero CL, Hyatt AD, Hengstberger S, Robinson AJ (1998) Isolation and characterization of iridoviruses from the giant toad Bufo marinus in Venezuela. Dis Aquat Org 33:1-9

Submitted: February 4, 2005; Accepted: March 31, 2006

Proofs received from author(s): August 25, 2006 